University of Nebraska - Lincoln

DigitalCommons@University of Nebraska - Lincoln

Roman L. Hruska U.S. Meat Animal Research

U.S. Department of Agriculture: Agricultural Center

Research Service, Lincoln, Nebraska

2014

\title{
Freezing and thawing or freezing, thawing, and aging effects on beef tenderness
}

\author{
A. L. Grayson \\ USDA-ARS \\ D. A. King \\ USDA-ARS, andy.king@usda.gov
}

S. D. Shackelford

USDA-ARS

M. Koohmaraie

IEH Laboratories and Consulting Group

T. L. Wheeler

USDA-ARS, tommy.wheeler@ars.usda.gov

Follow this and additional works at: https://digitalcommons.unl.edu/hruskareports

Grayson, A. L.; King, D. A.; Shackelford, S. D.; Koohmaraie, M.; and Wheeler, T. L., "Freezing and thawing or freezing, thawing, and aging effects on beef tenderness" (2014). Roman L. Hruska U.S. Meat Animal Research Center. 392.

https://digitalcommons.unl.edu/hruskareports/392

This Article is brought to you for free and open access by the U.S. Department of Agriculture: Agricultural Research Service, Lincoln, Nebraska at DigitalCommons@University of Nebraska - Lincoln. It has been accepted for inclusion in Roman L. Hruska U.S. Meat Animal Research Center by an authorized administrator of DigitalCommons@University of Nebraska - Lincoln. 


\title{
Freezing and thawing or freezing, thawing, and aging effects on beef tenderness $1,2,3$
}

\author{
A. L. Grayson,* D. A. King,* S. D. Shackelford,* M. Koohmaraie, †+ and T. L. Wheeler*4 \\ *Roman L. Hruska U.S. Meat Animal Research Center, USDA-ARS, Clay Center, NE 68933-0166; \\ $\dagger$ †EH Laboratories and Consulting Group, 15300 Bothell Way N.E., Lake Forest Park, WA 98155; \\ and $\ddagger$ College of Food and Agriculture, King Saud University, Riyadh, Saudi Arabia
}

\begin{abstract}
The objective of this study was to determine the effect of freezing and thawing or freezing and thawing with an additional aging period after frozen storage on the tenderness of longissimus lumborum (LL) and semitendinosus (ST) steaks relative to aged, fresh steaks. Left-side LL and ST ( $n=35$ each) were obtained from U.S. Select carcasses classified at the grading stand by the U.S. Meat Animal Research Center visible and near-infrared spectroscopy tenderness system to have predicted slice shear force greater than $16.5 \mathrm{~kg}$ at $14 \mathrm{~d}$ postmortem. At $2 \mathrm{~d}$ postmortem, $2.54 \mathrm{~cm}$ thick steaks were cut from each muscle and assigned to 1 of the following treatments: $2 \mathrm{~d}$ fresh (2FRESH), $2 \mathrm{~d}$ freeze + thaw (2FREEZE), $2 \mathrm{~d}$ freeze + thaw $+12 \mathrm{~d}$ age (2FREEZE+12AGE), $14 \mathrm{~d}$ fresh (14FRESH), $14 \mathrm{~d}$ freeze + thaw (14FREEZE), $14 \mathrm{~d}$ freeze + thaw $+14 \mathrm{~d}$ age (14FREEZE+14AGE), and $28 \mathrm{~d}$ fresh (28FRESH). Steaks assigned to a freezing treatment were frozen at $-26^{\circ} \mathrm{C}$ for $30 \mathrm{~d}$ before thawing/cooking or thawing with an additional aging period at $2^{\circ} \mathrm{C}$. Slice shear force for LL and ST was lower $(P<0.01)$ for 2FREEZE (27.4 and $24.5 \mathrm{~kg}$ ) and 14FREEZE (22.4 and $22.4 \mathrm{~kg}$ ) compared to 2FRESH (33.0 and $29.2 \mathrm{~kg}$ ) and 14FRESH (25.3 and $25.5 \mathrm{~kg}$ ), respectively. Slice shear force for LL
\end{abstract}

and ST was lower $(P<0.01)$ for 2FREEZE+12AGE $(17.8$ and $20.8 \mathrm{~kg}$ ) and 14FREEZE+14AGE (14.6 and $19.0 \mathrm{~kg})$ compared to 14FRESH (25.3 and $25.5 \mathrm{~kg}$ ) and 28FRESH (18.7 and $21.7 \mathrm{~kg}$ ), respectively. Desmin degradation for LL was not different $(P>0.05)$ between 2FREEZE $(21.0 \%)$ and 2FRESH (14.6\%) or between 14FREEZE (40.4\%) and 14FRESH (38.4\%); however, desmin degradation was higher $(P<0.06)$ in 2FREEZE+12AGE (46.7\%) and 14FREEZE+14AGE (71.1\%) when compared to 14FRESH $(38.4 \%)$ and 28FRESH $(60.5 \%)$, respectively. Cooking loss for LL was higher $(P<0.01)$ in 2FREEZE+12AGE (15.2\%) compared to 14FRESH $(14.0 \%)$ but was not different $(P>0.05)$ between 14FREEZE+14AGE (15.0\%) and 28FRESH (14.3\%). Freezing and thawing or a combination of freezing, thawing, and aging resulted in increased tenderness for LL and ST steaks when compared to fresh steaks with the same aging time. These results indicate freezing could be incorporated into normal commercial product distribution processes to improve the consistency of meat tenderness. Researchers who freeze steaks before tenderness assessment should be aware and acknowledge that freezing affects tenderness data.

Key words: aging, beef, freezing, quality, tenderness

(C) 2014 American Society of Animal Science. All rights reserved.

This document is a U.S. government work and

is not subject to copyright in the United States.

\footnotetext{
${ }^{1}$ Mention of trade names, proprietary products, or specified equipment does not constitute a guarantee or warranty by the USDA and does not imply approval to the exclusion of other products that may be suitable. The authors gratefully acknowledge the technical support of Patty Beska, Kristen Ostdiek, and Pat Tammen and the secretarial support of Jody Gallagher.

${ }^{2}$ USDA is an equal opportunity provider and employer.

${ }^{3}$ This study was funded in part by the Distinguished Scientist Fellowship Program, King Saud University, Saudi Arabia.

${ }^{4}$ Corresponding author: tommy.wheeler@ars.usda.gov

Received January 16, 2014.

Accepted March 6, 2014.
}

J. Anim. Sci. 2014.92:2735-2740 doi:10.2527/jas2014-7613

\section{INTRODUCTION}

Proteolysis of key structural myofibrillar proteins by $\mu$-calpain has been shown to be the primary cause of postmortem meat tenderization and is highly regulated by calpastatin (Koohmaraie, 1992, 1994). Calpastatin, but not calpain, has been shown to be sensitive to frozen storage, with calpastatin decreasing over time during frozen storage (Koohmaraie, 1990). Thus, freezing, thawing, and then aging might allow calpain to be more active and result in more proteolysis than from normal aging (Crouse and Koohmaraie, 1990; Whipple and 
Koohmaraie, 1992). Furthermore, freezing and thawing without additional aging might improve tenderness through structural damage from ice crystal formation (Hiner et al., 1945; Petrović et al., 1993). However, results of freezing on meat tenderness have been inconsistent (Hiner et al., 1945; Wheeler et al., 1990; Shanks et al., 2002; Hergenreder et al., 2013; Howard et al., 2013). These inconsistencies could be attributed to differences in the freezing and thawing parameters (Grujić et al., 1993) as well as the initial level of tenderness. Most research has addressed freezing after an aging period. Wheeler et al. (1990) found no difference in tenderness when steaks from frozen and fresh subprimals were compared after comparable aging times, whereas Shanks et al. (2002) found the opposite. However, research conducted on the effects of freezing followed by an additional aging period after frozen storage indicates this may be a viable tenderization strategy (Crouse and Koohmaraie, 1990).

A freezing/thawing or combination freezing/thawing/aging process could be a strategy to overcome toughness that is not resolved during normal postmortem aging. In addition, the effect of freezing and thawing on tenderness may be impacting research results for product normally marketed as fresh. Therefore, the objective of this study was to determine the effect of freezing and thawing or freezing and thawing with an additional aging period after frozen storage on tenderness of longissimus lumborum (LL) and semitendinosus (ST) steaks.

\section{MATERIALS AND METHODS}

\section{Carcass Selection and Sample Preparation}

United States Select carcasses $(n=35)$ were selected on the grading stand at a commercial beef packing plant using the U.S. Meat Animal Research Center (USMARC) visible and near-infrared spectroscopy tenderness classification system. Carcasses that were predicted to have slice shear force $(\mathbf{S S F})>16.5 \mathrm{~kg}$ at $14 \mathrm{~d}$ postmortem were selected. Untrimmed subprimals were fabricated from the left sides of the 35 carcasses at $1 \mathrm{~d}$ postmortem according to the Institutional Meat Purchase Specification (IMPS) for IMPS number 180 boneless strip loin and IMPS number 171C boneless eye of round (NAMP, 2003; USDA, 2010), collected into a combo bin unpackaged, and transported at $0^{\circ} \mathrm{C}$ to the USMARC and stored at $2^{\circ} \mathrm{C}$. At $2 \mathrm{~d}$ postmortem, each subprimal was trimmed of external fat and accessory muscles to yield LL and ST muscles. The muscles were cut into $2.54 \mathrm{~cm}$ steaks and assigned to 1 of 7 treatments by blocking for within muscle location such that each treatment occurred in each location an equal number of times. Treatments included $2 \mathrm{~d}$ fresh (2FRESH), 2 $\mathrm{d}$ freeze + thaw (2FREEZE), $2 \mathrm{~d}$ freeze + thaw $+12 \mathrm{~d}$ age (2FREEZE+12AGE), $14 \mathrm{~d}$ fresh (14FRESH), $14 \mathrm{~d}$ freeze + thaw (14FREEZE), $14 \mathrm{~d}$ freeze + thaw $+14 \mathrm{~d}$ age (14FREEZE+14AGE), and $28 \mathrm{~d}$ fresh (28FRESH). Steaks were vacuum packaged in oxygen barrier film. Steaks that were assigned a freeze treatment were frozen for $30 \mathrm{~d}$ at $-26 \pm 2{ }^{\circ} \mathrm{C}$ after aging at $2^{\circ} \mathrm{C}$ the appropriate amount of time ( 2 or $14 \mathrm{~d}$ ). The FREEZE treatment steaks then were thawed for $24 \mathrm{~h}$ at $5^{\circ} \mathrm{C}$ and processed for SSF. Steaks that were assigned to a freeze/thaw/age treatment after aging for 2 or $14 \mathrm{~d}$ also were frozen for $30 \mathrm{~d}$ at $-26 \pm$ $2^{\circ} \mathrm{C}$ but then were thawed at $2^{\circ} \mathrm{C}$ and aged at $2^{\circ} \mathrm{C}$ for an additional period of time (12 $\mathrm{d}$ for $2 \mathrm{FREEZE}+12 \mathrm{AGE}$ treatment or $14 \mathrm{~d}$ for 14FREEZE+14AGE treatment; aging time after freezing included thawing time). The freeze + age steaks were equilibrated to $5^{\circ} \mathrm{C}$ for the final $16 \mathrm{~h}$ before cooking. This design provided a fresh control with the same total postmortem aging time to compare to each freeze/thaw or freeze/thaw/age treatment. Freezing and frozen storage occurred at an average temperature of $-26 \pm$ $2^{\circ} \mathrm{C}$. All aging, freezing, frozen storage, and thawing was conducted with single layers of vacuum-packaged steaks to ensure consistency among treatments.

\section{Cooking Loss and Slice Shear Force}

All steaks were equilibrated in a refrigerator to $5^{\circ} \mathrm{C}$ (16 h) before cooking. Raw and cooked weights were collected to determine cook loss percentage with the equation of [(thawed weight - cooked weight)/thawed weight] $\times$ 100. Steaks were cooked on a belt grill (model TBG-60 Magigrill; MagiKitch'n Inc., Quakertown, PA) using a program designed to achieve a final internal temperature of $71^{\circ} \mathrm{C}$ using the methods of Wheeler et al. (1998). As steaks exited the belt grill, a needle thermocouple (Type J; Omega Engineering, Stamford, CT) was inserted in the geometric center of each steak. The temperature was monitored using a handheld thermometer (Cole-Parmer, Vernon Hills, IL) until peak temperature was reached.

Slice shear force was conducted using methods described by Shackelford et al. (1999). For LL, 1 slice was obtained parallel to the muscle fibers from the lateral end of the steak and sheared, and peak shear force was recorded. For ST, 3 slices were collected parallel to the muscle fiber and sheared, and peak shear force was recorded (USMARC, 2012). Sheared slices from LL were used for immunoblotting to determine extent of postmortem proteolysis.

\section{Immunoblotting}

Cooked LL samples from SSF remnants were used to determine the extent of postmortem proteolysis of desmin by methods described in Wheeler et al. (2002). All treatments from 1 subprimal were run on 1 gel. Treatments were rotated on the gel to block for potential gel location effects. An at-death standard from LM was 
Table 1. Least squares means, SD, minimum, and maximum values for slice shear force for the longissimus lumborum

\begin{tabular}{lcccc}
\hline \hline Treatment $^{1}$ & Mean $^{2}$ & SD & Minimum & Maximum \\
\hline 2FRESH & $33.0^{\mathrm{c}}$ & 4.3 & 27.0 & 44.6 \\
2FREEZE & $27.4^{\mathrm{d}}$ & 5.9 & 17.7 & 39.3 \\
2FREEZE+12AGE & $17.8^{\mathrm{f}}$ & 3.6 & 11.3 & 24.1 \\
14FRESH & $25.3^{\mathrm{d}}$ & 5.5 & 17.1 & 40.5 \\
14FREEZE & $22.4^{\mathrm{e}}$ & 5.0 & 13.6 & 34.6 \\
14FREEZE+14AGE & $14.6^{\mathrm{g}}$ & 4.2 & 10.1 & 30.7 \\
28FRESH & $18.7^{\mathrm{f}}$ & 5.0 & 11.6 & 31.0 \\
\hline
\end{tabular}

${ }^{\mathrm{c}-\mathrm{g}}$ Means in a column lacking a common superscript differ $(P<0.05)$, $\mathrm{SEM}=0.82$.

${ }^{1} 2$ FRESH $=2 \mathrm{~d}$ fresh $; 2$ FREEZE $=2 \mathrm{~d}$ freeze + thaw $; 2$ FREEZE $+12 \mathrm{AGE}=$ $2 \mathrm{~d}$ freeze + thaw $+12 \mathrm{~d}$ age $; 14$ FRESH $=14 \mathrm{~d}$ fresh ; 14FREEZE $=14$ $\mathrm{d}$ freeze + thaw $;$ 14FREEZE $+14 \mathrm{AGE}=14 \mathrm{~d}$ freeze + thaw $+14 \mathrm{~d}$ age ; 28FRESH $=28 \mathrm{~d}$ fresh.

${ }^{2}$ Expressed in kilograms.

used to normalize the data within blots and determine differences in desmin degradation.

\section{Statistical Analysis}

Data were analyzed for a randomized complete block design with the main effect of treatment blocked by within muscle location using the PROC GLIMMIX function in SAS 9.3 (SAS Inst. Inc., Cary, SC). Analysis of variance was conducted for the fixed effect of treatment (2FRESH, 2FREEZE, 2FREEZE+12AGE, 14FRESH, 14FREEZE, 14FREEZE+14AGE, and 28FRESH). Least squares means were calculated and separated using the PDIFF function of SAS. Slice shear force data were analyzed independently for each muscle because measures of shear force do not accurately reflect tenderness differences between muscles (Shackelford et al., 1995; Rhee et al., 2004), and shear force does not accurately represent the contribution of connective tissue to muscle tenderness (Bouton et al., 1978; Harris and Shorthose, 1988).

\section{RESULTS AND DISCUSSION}

\section{Slice Shear Force (Longissimus Lumborum)}

Steaks from 14FREEZE+14AGE had the lowest $(P<0.01)$ mean SSF, whereas steaks from 2FRESH had the highest $(P<0.01)$ mean SSF for LL steaks (Table 1$)$. Slice shear force for LL steaks was lower $(P<0.01)$ for 2FREEZE and 14FREEZE compared to 2FRESH and 14FRESH, respectively. Slice shear force for LL steaks was lower $(P<0.01)$ for 2FREEZE+12AGE and 14FREEZE+14AGE compared to 14FRESH and 28FRESH, respectively. Freezing and thawing, whether applied to steaks at 2 or $14 \mathrm{~d}$ postmortem, increased $(P<$ $0.01)$ tenderness relative to fresh LL steaks. In addition,
Table 2. Least squares means, $\mathrm{SD}$, minimum, and maximum values for slice shear force for the semitendinosus

\begin{tabular}{lcccc}
\hline \hline Treatment $^{1}$ & Mean $^{2}$ & SD & Minimum & Maximum \\
\hline 2FRESH & $29.2^{\mathrm{c}}$ & 3.4 & 18.4 & 38.9 \\
2FREEZE & $24.5^{\mathrm{d}}$ & 2.6 & 19.1 & 29.2 \\
2FREEZE+12AGE & $20.8^{\mathrm{e}}$ & 2.8 & 18.0 & 28.1 \\
14FRESH & $25.5^{\mathrm{d}}$ & 2.7 & 16.9 & 27.2 \\
14FREEZE & $22.4^{\mathrm{e}}$ & 2.6 & 16.4 & 26.1 \\
14FREEZE+14AGE & $19.0^{\mathrm{f}}$ & 3.2 & 17.5 & 31.3 \\
28FRESH & $21.7^{\mathrm{e}}$ & 3.9 & 20.6 & 37.0 \\
\hline
\end{tabular}

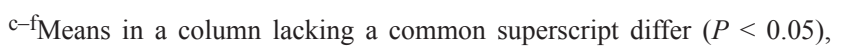
$\mathrm{SEM}=0.64$.

$1_{2}$ FRESH $=2 \mathrm{~d}$ fresh $; 2$ FREEZE $=2 \mathrm{~d}$ freeze + thaw $; 2$ FREEZE $+12 \mathrm{AGE}=$ $2 \mathrm{~d}$ freeze + thaw $+12 \mathrm{~d}$ age $; 14$ FRESH $=14 \mathrm{~d}$ fresh ; 14FREEZE $=14$ $\mathrm{d}$ freeze + thaw ; 14FREEZE+14AGE $=14 \mathrm{~d}$ freeze + thaw $+14 \mathrm{~d}$ age ; 28FRESH $=28 \mathrm{~d}$ fresh.

${ }^{2}$ Expressed in kilograms.

freezing, thawing, and then aging, whether applied to LL steaks at 2 or $14 \mathrm{~d}$ postmortem, increased $(P<0.01)$ tenderness relative to freezing and thawing alone and increased $(P<0.01)$ tenderness relative to fresh LL steaks with the same total aging time.

\section{Slice Shear Force (Semitendinosus)}

Steaks from 14FREEZE+14AGE had the lowest $(P<0.01)$ mean SSF, whereas steaks from 2FRESH had the highest $(P<0.01)$ mean SSF for ST steaks (Table 2$)$. Slice shear force for ST steaks was lower $(P<0.01)$ for 2FREEZE and 14FREEZE compared to 2FRESH and 14FRESH, respectively. Slice shear force for ST steaks was lower $(P<0.01)$ for 2FREEZE+12AGE and 14FREEZE+14AGE compared to 14FRESH and 28FRESH, respectively. Freezing and thawing, whether applied to steaks at 2 or $14 \mathrm{~d}$ postmortem, increased $(P<$ $0.01)$ tenderness relative to fresh ST steaks. In addition, freezing, thawing, and then aging, whether applied to ST steaks at 2 or $14 \mathrm{~d}$ postmortem, increased $(P<0.01)$ tenderness relative to freezing and thawing alone and increased $(P<0.01)$ tenderness relative to fresh ST steaks with the same total aging time.

\section{Proteolysis}

Desmin degradation in LL was highest $(P<0.01)$ for 14FREEZE+14AGE and lowest $(P<0.01)$ for 2FRESH and 2FREEZE (Table 3). Desmin degradation for LL was not different $(P>0.05)$ between 2FREEZE and 2FRESH or between 14FREEZE and 14FRESH. However, desmin degradation was higher $(P<0.06)$ in 2FREEZE+12AGE and 14FREEZE+14AGE when compared to 14FRESH and 28FRESH, respectively. Therefore, freezing did not affect the proteolysis that occurred during thawing. 
Table 3. Least squares means, $\mathrm{SD}$, minimum, and maximum values for percentage of desmin degradation for the longissimus lumborum

\begin{tabular}{llccc}
\hline \hline Treatment $^{1}$ & Mean & SD & Minimum & Maximum \\
\hline 2FRESH & $14.6^{\mathrm{f}}$ & 16.4 & 0.0 & 62.2 \\
2FREEZE & $21.0^{\mathrm{f}}$ & 16.4 & 0.0 & 57.6 \\
2FREEZE+12AGE & $46.7^{\mathrm{d}}$ & 19.0 & 12.8 & 100.0 \\
14FRESH & $38.4^{\mathrm{e}}$ & 18.1 & 0.0 & 82.2 \\
14FREEZE & $40.4^{\mathrm{de}}$ & 20.2 & 0.0 & 85.1 \\
14FREEZE+14AGE & $71.1^{\mathrm{b}}$ & 18.3 & 20.7 & 100.0 \\
28FRESH & $60.5^{\mathrm{c}}$ & 21.0 & 14.0 & 97.9 \\
\hline
\end{tabular}

$\mathrm{b}, \mathrm{c}, \mathrm{d}, \mathrm{e}, \mathrm{f}$ Means in a column lacking a common super script differ $(P<0.06)$, $\mathrm{SEM}=3.08$

${ }^{1} 2$ FRESH $=2 \mathrm{~d}$ fresh $; 2$ FREEZE $=2 \mathrm{~d}$ freeze + thaw $; 2$ FREEZE $+12 \mathrm{AGE}=$ $2 \mathrm{~d}$ freeze + thaw $+12 \mathrm{~d}$ age $; 14$ FRESH $=14 \mathrm{~d}$ fresh ; 14FREEZE $=14$ $\mathrm{d}$ freeze + thaw ; 14FREEZE+14AGE $=14 \mathrm{~d}$ freeze + thaw $+14 \mathrm{~d}$ age ; $28 \mathrm{FRESH}=28 \mathrm{~d}$ fresh.

However, in LL freeze/thaw/age increased the level of proteolysis over fresh aging for the same amount of time.

The increases in tenderness observed in this study were likely from 2 sources. Freezing and thawing without an additional aging period most likely resulted in structural damage due to ice crystal formation as described by Hiner et al. (1945) and Grujić et al. (1993). This conclusion is supported by the reduced SSF but similar level of desmin degradation in freeze/thaw treatments relative to fresh treatments. The effect of freeze/ thaw/age treatments on tenderness were likely the result of both ice crystal damage and enhanced proteolysis. This conclusion is supported by the greater reduction in SSF and greater percentage of desmin degradation in freeze/thaw/age treatments relative to fresh treatments with the same total aging time.

These increases in postmortem proteolysis for 14FREEZE+14AGE and 2FREEZE+12AGE degradation relative to $28 \mathrm{FRESH}$ and $14 \mathrm{FRESH}$, respectively, were likely the result of calpastatin inactivation during freezing (Koohmaraie, 1990), which allowed increased calpain activity during the postfreezing aging period. Higher amounts of calpastatin have a significant impact on tenderness, thus application of methods to deplete calpastatin levels, such that tenderization during aging is enhanced, could be important to the meat industry. A freezing, thawing, and subsequent aging period could be used for meat from animals with higher calpastatin levels (e.g., certain genetics and some growth promotant strategies) to improve the consistency of tenderness.

Slice shear force results from the LL and ST support Hiner et al. (1945), Crouse and Koohmaraie (1990), and Shanks et al. (2002), where freezing resulted in improvements in tenderness, but disagrees with others (Smith et al., 1968; Berry et al., 1971; Wheeler et al., 1990; Hergenreder et al., 2013). Hergenreder et al. (2013) found no effect on sensory tenderness rating for ribeye, strip loin, or top sirloin steaks regardless of rate of freezing or thawing the subprimals. Howard et al. (2013) reported that freezing and thawing reduced mean Warner-Bratzler shear force by $0.4 \mathrm{~kg}$, but mean SSF was not affected. The magnitude of the improvements in tenderness (Tables 1 and 2) could partly be a result of selecting carcasses that were predicted to have tough meat. These data also agree with Crouse and Koohmaraie (1990) in that aging after freezing resulted in a larger increase in tenderness than those only aged before being frozen and those frozen and thawed without additional aging. Freezing and thawing with subsequent aging shows the greatest improvement in tenderness when compared to fresh samples. However, the use of freezing alone should not be disregarded as freezing and thawing without additional aging also improved tenderness over fresh samples. In fact, one-fourth to one-third of the LL tenderness increase from freeze/ thaw/age was due to proteolysis leaving two-thirds to three-fourths due to freezing alone. Furthermore, all of the tenderness increase in ST from freeze/thaw/age could be accounted for by freezing effects.

Because some meat will still be tough after typical refrigerated aging and could benefit from freezing or freezing followed by an additional aging period to improve postmortem tenderization, freezing could be useful in foodservice and the export market. It also is compatible with the strategy of stocking up on meat during seasonal price fluctuations.

Freezing and thawing of LL samples also could affect tenderness results in research data because the freezing effect is greater on tougher samples (less postmortem aging; Shanks et al., 2002). Longissimus steaks with $14 \mathrm{~d}$ postmortem aging are often used for tenderness evaluation in research. Often time constraints on research laboratories require samples to be frozen until time allows for tenderness analysis. If trying to determine the effect of a treatment on tenderness at $14 \mathrm{~d}$ postmortem on longissimus steaks, freezing likely will result in overestimating the level of tenderness and could prevent detection of real differences in tenderness between treatments (Howard et al., 2013).

\section{Cooking Loss}

Longissimus lumborum steaks from 2FREEZE and 14FREEZE had the highest $(P<0.05)$ cooking losses compared to all other treatments (Table 4). Higher $(P<$ 0.05 ) cooking losses resulted from 2FREEZE+12AGE compared to 14FRESH but not for 14FREEZE+14AGE compared to 28FRESH $(P>0.05)$. Differences in cooking loss for LL samples that were frozen most likely resulted from damage done to fibers or cellular membranes from ice crystal formation (Hiner et al., 1945; Grujić et al., 1993). Damage to the fibers or cellular membranes could inhibit 
Table 4. Least squares means, SD, minimum, and maximum values for cook loss for the longissimus lumborum ${ }^{1}$

\begin{tabular}{llccc}
\hline \hline Treatment $^{2}$ & Mean & SD & Minimum & Maximum \\
\hline 2FRESH & $14.3^{\mathrm{ef}}$ & 1.9 & 10.0 & 18.7 \\
2FREEZE & $16.2^{\mathrm{c}}$ & 1.5 & 12.2 & 18.6 \\
2FREEZE+12AGE & $15.2^{\mathrm{d}}$ & 1.3 & 13.3 & 18.9 \\
14FRESH & $14.0^{\mathrm{f}}$ & 1.7 & 10.5 & 18.0 \\
14FREEZE & $16.0^{\mathrm{c}}$ & 1.8 & 11.7 & 20.8 \\
14FREEZE+14AGE & $15.0^{\mathrm{de}}$ & 1.4 & 11.6 & 17.6 \\
28FRESH & $14.3^{\mathrm{ef}}$ & 1.2 & 12.3 & 17.3 \\
\hline
\end{tabular}

${ }^{\mathrm{c}-\mathrm{f}}$ Means in a column lacking a common super script differ $(P<0.05)$, $\mathrm{SEM}=0.27$.

${ }^{1}$ Values expressed as a percentage of cook loss calculated using the equation [(thawed weight - cooked weight $) /$ thawed weight] $\times 100$.

${ }^{2} 2 \mathrm{FRESH}=2 \mathrm{~d}$ fresh $; 2 \mathrm{FREEZE}=2 \mathrm{~d}$ freeze + thaw $; 2 \mathrm{FREEZE}+12 \mathrm{AGE}=$ $2 \mathrm{~d}$ freeze + thaw $+12 \mathrm{~d}$ age $; 14$ FRESH $=14 \mathrm{~d}$ fresh $;$ 14FREEZE $=14$ $\mathrm{d}$ freeze + thaw $;$ 14FREEZE+14AGE $=14 \mathrm{~d}$ freeze + thaw $+14 \mathrm{~d}$ age; $28 \mathrm{FRESH}=28 \mathrm{~d}$ fresh.

the ability to hold water, resulting in the increase in cooking loss that was observed for the LL. Lower cooking loss in steaks aged after freezing/thawing relative to just freezing and thawing was likely due to greater water loss as purge during aging, although purge loss was not measured. The general trend for cooking loss was higher for freeze/thaw treatments, intermediate for freeze/thaw/age treatments, and lower for fresh treatments. If it had been measured, it is likely that purge during aging would have helped explain some of the treatment differences in cooking loss. Differences in cooking loss found in this study for the LL were in general agreement with Crouse and Koohmaraie (1990), Wheeler et al. (1990), and Shanks et al. (2002).

There were no differences $(P=0.31)$ among treatments for cooking loss for the ST (Table 5). However, it appeared that ST had greater cooking loss than LL for all treatments. The high cooking loss of ST relative to other muscles is consistent with cooking loss differences previously reported (Rhee et al., 2004; Shackelford et al., 1997) and is likely in part due to differences in connective tissue shrinkage during cooking that forces more water out of the muscle (Davey and Gilbert, 1974; Purslow, 2005). The cooking loss differences also could be related to differences in muscles fiber orientation relative to the steak surface and sarcomere length with ST fibers perpendicular to the steak surface and sarcomere length longer (Rhee et al., 2004). The cooking loss difference is not likely due to differences in rate of freezing or thawing since all steaks were the same thickness and were laid out in a single layer for freezing and thawing.

Among treatments, cooking loss and purge loss could be affected by the temperature that the product is frozen, the rate of freezing, the length of frozen storage, and the rate of thawing. Increases in moisture loss would be undesirable; therefore, it would be important to minimize those losses by optimizing the freezing/thawing process-
Table 5. Least squares means, $\mathrm{SD}$, minimum, and maximum values for cook loss for the semitendinosus ${ }^{1}$

\begin{tabular}{lcccc}
\hline \hline Treatment $^{2}$ & Mean $^{3}$ & SD & Minimum & Maximum \\
\hline 2FRESH & 17.4 & 2.0 & 13.6 & 21.2 \\
2FREEZE & 19.8 & 2.1 & 14.8 & 23.3 \\
2FREEZE+12AGE & 21.1 & 1.9 & 14.0 & 22.4 \\
14FRESH & 18.7 & 1.8 & 14.1 & 21.3 \\
14FREEZE & 20.7 & 2.7 & 14.7 & 25.6 \\
14FREEZE+14AGE & 18.5 & 2.1 & 13.8 & 22.7 \\
28FRESH & 20.9 & 2.2 & 9.7 & 21.3 \\
\hline
\end{tabular}

${ }^{1}$ Values expressed as a percentage of cook loss calculated using the equation [(thawed weight - cooked weight $) /$ thawed weight] $\times 100$.

${ }^{2} 2 \mathrm{FRESH}=2 \mathrm{~d}$ fresh $; 2$ FREEZE $=2 \mathrm{~d}$ freeze + thaw $; 2$ FREEZE $+12 \mathrm{AGE}=$ $2 \mathrm{~d}$ freeze + thaw $+12 \mathrm{~d}$ age $; 14$ FRESH $=14 \mathrm{~d}$ fresh ; 14FREEZE $=14$ $\mathrm{d}$ freeze + thaw $;$ 14FREEZE+14AGE $=14 \mathrm{~d}$ freeze + thaw $+14 \mathrm{~d}$ age ; 28FRESH $=28 \mathrm{~d}$ fresh.

${ }^{3}$ No difference between treatments $(P>0.05), \mathrm{SEM}=1.29$.

es. Pearson and Miller (1950) found no difference in the amount of drip loss or cook loss between different rates of freezing; however, both drip loss and cook loss percentages tended to increase with increasing length of frozen storage time. Conversely, Hiner et al. (1945) determined that ice crystal formation, both intracellular and intercellular, caused damage to the sarcolemma and myofibrils, resulting in the inability of the fibers to retain moisture. Hiner et al. (1945) also determined that freezing at $-7.8^{\circ} \mathrm{C}$ resulted in higher proportional drip loss compared to freezing at $-40^{\circ} \mathrm{C}$. This difference was attributed to where ice crystal formation occurred. They determined that ice crystals that were formed intracellularly were reabsorbed more in comparison to ice crystals formed intercellularly. In agreement with those findings, Grujić et al. (1993) and Petrović et al. (1993) showed that faster freezing (as long as it was at less than $-70^{\circ} \mathrm{C}$ ) provided small, intracellular ice crystals that minimized water loss from tissue damage and maximized sensory tenderness. Hergenreder et al. (2013) determined that boneless strip loin, ribeye roll, and top sirloin subprimals that were thawed slower had higher thaw loss and steaks from the fast-thawed subprimals had higher purge loss during $8 \mathrm{~d}$ of display. Combined display and thaw losses were greater for the slow thawed treatments. However, only strip loin steaks had higher cooking loss and lower juiciness ratings from frozen compared to fresh subprimals, regardless of freezing or thawing rate.

In summary, these results indicate that freezing and thawing or freezing, thawing, and aging reduces SSF by 10 to $20 \%$ and may be a viable option to improve the consistency of meat tenderness. These processes could be implemented to take advantage of seasonal fluctuations in meat prices and distribution time for domestic and export markets. Freezing is not likely to be adopted industry-wide, but there may be niches where the advantages outweigh the disadvantages. In this sample of relatively tough meat, similar results were obtained whether freezing early $(2 \mathrm{~d})$ or later 
(14 d) postmortem. Further research is needed to optimize the processes for steaks and subprimals and to determine the extent of the effects on sensory properties, purge loss, color, fat oxidation, and other potentially impacted economically important traits. The optimum freezing and thawing processes with current commercial technology needs to be determined to maximize tenderness and other quality traits and minimize moisture losses and other negative effects to make a freezing strategy a viable option. Researchers who freeze steaks before tenderness assessment should be aware and acknowledge that freezing affects tenderness data.

\section{LITERATURE CITED}

Berry, B. W., G. C. Smith, J. V. Spencer, and G. H. Kroening. 1971. Effects of freezing method, length of frozen storage and cookery from the thawed or frozen state on palatability characteristics of pork. J. Anim. Sci. 32:636-640.

Bouton, P. E., A. L. Ford, P. V. Harris, W. R. Shorthose, D. Ratcliff, and J. H. L. Morgan. 1978. Influence of animal age on the tenderness of beef: Muscle differences. Meat Sci. 2:301-311.

Crouse, J. D., and M. Koohmaraie. 1990. A research note: Effect of freezing of beef on subsequent postmortem aging and shear force. J. Food Sci. 55:573-574.

Davey, C. L., and K. V. Gilbert. 1974. Temperature-dependent cooking toughness in beef. J. Sci. Food Agric. 25:931-938.

Grujić, R., L. Petrović, B. Pikula, and L. Amidzić. 1993. Definition of the optimum freezing rate- 1 . Investigation of structure and ultrastructure of beef $\mathrm{M}$. longissimus dorsi frozen at different freezing rates. Meat Sci. 33:301-318.

Harris, P. V., and W. R. Shorthose. 1988. Meat texture. In: R. A. Lawrie, editor, Developments in meat science - 4. Elsevier Applied Science Publishers, London. p. 245-286.

Hergenreder, J. E., J. J. Hosch, K. A. Varnold, A. L. Haack, L. S. Senaratne, S. Poklarel, C. Beauchamp, B. Lobaugh, and C. R. Calkins. 2013. The effects of freezing and thawing rates on tenderness, sensory quality, and retail display of beef subprimals. J. Anim. Sci. 91:483-490.

Hiner, R. L., L. L. Madsen, and O. G. Hankins. 1945. Histological characteristics, tenderness and drip losses of beef in relation to temperature of freezing. J. Food Sci. 10:312-324.

Howard, S. T., D. R. Woerner, J. A. Scanga, D. L. VanOverbeke, G. G. Mafi, J. L. Igo, M. D. Salman, J. D. Tatum, and K. E. Belk. 2013. North American beef tenderness survey 2011-2012: Benchmarking tenderness and sample shipping procedures. J. Anim. Sci. 91:5981-5988.

Koohmaraie, M. 1990. Quantification of $\mathrm{Ca}^{2+}$-dependent protease activities by hydrophobic and ion-exchange chromatography. J. Anim. Sci. 68:659-665.

Koohmaraie, M. 1992. The role of $\mathrm{Ca}^{2+}$-dependent proteases (calpains) in post mortem proteolysis and meat tenderness. Biochimie 74:239-245.
Koohmaraie, M. 1994. Muscle proteinases and meat aging. Meat Sci. 36:93-104.

North American Meat Processors Association (NAMP). 2003. Meat buyers guide. NAMP, Reston, VA.

Pearson, A. M., and J. I. Miller. 1950. The influence of rate of freezing and length of freezer-storage upon the quality of beef of known origin. J. Anim. Sci. 9:13-19.

Petrović, L., R. Grujić, and M. Petrović. 1993. Definition of the optimal freezing rate-2. Investigation of the physic-chemical properties of beef M. longissimus dorsi frozen at different freezing rates. Meat Sci. 33:319-331.

Purslow, P. P. 2005. Intramuscular connective tissue and its role in meat quality. Meat Sci. 70:435-447.

Rhee, M. S., T. L. Wheeler, S. D. Shackelford, and M. Koohmaraie. 2004. Variation in palatability and biochemical traits within and among eleven beef muscles. J. Anim. Sci. 82:534-550.

Shackelford, S. D., T. L. Wheeler, and M. Koohmaraie. 1995. Relationship between shear force and trained sensory panel tenderness ratings of 10 major muscles from Bos indicus and Bos taurus cattle. J. Anim. Sci. 73:3333-3340.

Shackelford, S. D., T. L. Wheeler, and M. Koohmaraie. 1997. Repeatability of tenderness measurements in beef round muscles. J. Anim. Sci. 75:2411-2416.

Shackelford, S. D., T. L. Wheeler, and M. Koohmaraie. 1999. Evaluation of slice shear force as an objective method of assessing beef longissimus tenderness. J. Anim. Sci. 77:2693-2699.

Shanks, B. C., D. M. Wulf, and R. J. Maddock. 2002. Technical note: The effect of freezing on Warner-Bratzler shear force values of beef longissimus steaks across several postmortem aging periods. J. Anim. Sci. 80:2122-2125.

Smith, G. C., C. W. Spaeth, Z. L. Carpenter, G. T. King, and K. E. Hoke. 1968. The effects of freezing, frozen storage conditions and degree of doneness on lamb palatability characteristics. J. Food Sci. 33:19-24.

USDA. 2010. IMPS 100 fresh beef. USDA Agricultural Marketing Service. Accessed Dec. 17, 2013. www.ams.usda.gov/ AMSv1.0/getfile?dDocName=STELDEV3003281.

U.S. Meat Animal Research Center (USMARC). 2012. USMARC slice shear force procedure for beef semitendinosus (ST). www. ars.usda.gov/sp2UserFiles/Place/54380530/protocols/SSF_ PROCEDURE_ST.pdf. (Accessed August 2013.)

Wheeler, T. L., R. K. Miller, J. W. Savell, and H. R. Cross. 1990. Palatability of chilled and frozen beef steaks. J. Food Sci. 55:301-304.

Wheeler, T. L., S. D. Shackelford, and M. Koohmaraie. 1998. Cooking and palatability traits of beef longissimus steaks cooked with a belt grill or an open hearth electric broiler. J. Anim. Sci. 76:2805-2810.

Wheeler, T. L., S. D. Shackelford, and M. Koohmaraie. 2002. Technical note: Sampling methodology for relating sarcomere length, collagen concentration and the extent of postmortem proteolysis to beef and pork longissimus tenderness. J. Anim. Sci. 80:982-987.

Whipple, G., and M. Koohmaraie. 1992. Freezing and calcium chloride marination effects on beef tenderness and calpastatin activity. J. Anim. Sci. 70:3081-3085. 